УДК 304:316.356.4(4/5):316.73

DOI: $10.32340 / 2514-772 X-2020-1-11-13$

В. А. Алемасов, доктор философских наук, профессор

Государственный институт искусства и культуры Узбекистана (Ташкент, Узбекистан) alemasov_49@mail.ru

\title{
ОБЩИЙ КУЛЬТУРНЫЙ КОД НАРОДОВ ЕВРАЗИИ И ЕГО СОЦИАЛЬНЫЕ ФАКТОРЫ
}

Аннотация. В статье утверждается мысль о том, что народы Евразии имеют не только собственные истории, культуры, менталитет и традиции, а также общий культурный код. Знание этого кода дает возможность создать общее евразийское культурное пространство, где многогранная интеграция и сотрудничество этносов, нации и государств обретают объективно закономерный характер.

Ключевые слова: культура, евразийиы, культурный код, интеграция, взаимодействие, менталитет, этносы, государства, иенности, межгосударственное общение.

Обретение независимости народами бывших советских республик дало им возможность самостоятельно определить стратегии и пути социально-политического, экономического и культурного развития, объективно изучать исторические опыты, по-новому строить свои отношения с бывшими «братскими народами». Задачи эти решались по-разному, независимые государства, их лидеры, по выражению известной исследовательницы региона Центральной Азии М. Б. Олкотт, «были увлечены стратегиями формирования наций, максимизировавшими соперничество и минимизировавшими сотрудничество» $[1$, c. 30$]$. Такой подход привел к тому, что фактически раньше существовавшие связи прекратились, каждая республика старалась показать и доказать свое культурное превосходство, а в некоторых республиках этноэгоизм чуть ли не стал государственной политикой. Поэтому возвращение к национальным традициям, но с соблюдением принципов современного международного права и интеграции, цивилизационного сотрудничества до сих пор еще не достигнуто. Мы забыли наш общий культурный код, который интегрировал нас, нашу экономику, социально-политические стремления, образ жизни, формировал у нас общее духовнонравственные установки, взаимопонимание.

«Культурный код-это бессознательный смысл той или иной вещи или явления, будь то машина, еда, отношения, даже страна в контексте культуры, в которой мы воспитаны» [2, с. 13]. Бессознательное - такое содержание психической жизни, о наличии которых человек, этносы в данный момент или длительное время не подозревают его присутствие в повседневной жизни [3, с. 440]. Но бессознательное, вошедшее в образ жизни, менталитет и интеграционные процессы невозможно искоренить, оно рано или поздно, сопро- вождая зарождение новых взаимоотношений, новых субъектов политики сотрудничества и интеграции этнокультур, выйдет наружу. Не зная или игнорируя этого неискоренимое бессознательное, в нашем примере общего культурного кода народов Евразии, невозможно строить новые связи, новые формы сотрудничества.

Общий культурный код, (известный основоположник русско-американской социологической школы П. А. Сорокин его называл, «родовое свойство, общих для всех социокультурных явлений прошлых, настоящих и будущих» [4, с. 190], народов Евразии формировался под влиянием нескольких социальных факторов.

Во-первых, у народов Евразии общая историческая судьба. Эта судьба определена, если использовать теологический термин, «Богом». Они, т. е. народы Евразии, жили и живут как соседи, у которых и радости и печали общие. Таких соседей не выбирают, с ними необходимо наладить связи, опираться на их поддержки, можно с ними спорить и даже ссорится, но невозможно их отвергать, игнорировать. История не оставила шанса народам Евразии выбирать соседа, она поставила их в такие условия, где можно было выжить, только поддерживая друг друга. Походы завоевателей вызвали такие психоэмоциальные отношения, которые духовно и ментально сблизили этносы, сформировали у них схожие представления о родине, патриотизме, добре и зле, жизнелюбии. Такие психоэмоциальные переживания, сочетающие некий, в нашем примере исторический, опыт и сопровождающие его эмоции называются «импринтингом» (термин К. Лоренца). Импринтинг в формировании исторического сознания, осознания общности исторической судьбы занимает доминирующее место. Недаром К. Рапай, говоря о импринтинге К. Лоренца, пишет, что психоэмоционально «запе- 
чатленный образ управляет мышлением и определяет наши действия в будущем. Каждый такой след в памяти добавляет черточку в наш характер, а совокупность таких отпечатков создает личность», общность [2, с. 14]. Импринтинг могут забыть отдельные люди, но народы - никогда. Не желание отдельных, пусть и крупных, с точки зрения истории, личностей, а народы, этносы, по велению законов выживания создавали свою общую историческую судьбу. Примером может являться участие в походах Чингисхана моголов-христиан (несториан), буддистов, даосистов, мусульман, христиан и многочисленных сторонников религии бон [5, с. 31]. Поэтому евразийское пространство формировалось благодаря общности исторической судьбы народов России и Центральной Азии. А импиринтинг до сих пор остается основным историко-психологическим, детерминирующим фактором евразийского сотрудничества.

Во-вторых, формированию общего культурного кода способствовали торгово-экономические связи. Ярким примером этого может служить Великий шелковый путь, раскинувшийся на огромных пространствах от Китая до Европы. Почти 17 веков просуществовали торгово-экономические связи государств, участвовавших в этом международном проекте.

«Парад суверенитетов», начавшийся в конце 90-годов XX века, разрушил многие, исторически сложившиеся культурные, экономические связи, и Евразия оказалась на пороге гуманитарной катастрофы. Стремление народов, национальных государств каким-то образом наладить свою социально-экономическую жизнь, сотрудничество не увенчались успехом. До 2000 года еще не сформировалось понимания, что в евразийском пространстве ведущую роль играла и будет продолжать играть Россия. Пока Россия не восстановит свою экономику, не наладит торгово-экономические связи с соседями, ни в одной республике не будет экономического успеха. Поэтому мы должны признать, что в евразийском пространстве есть, в лице России, лидер, чья позиция, успехи и стратегия партнерства детерминирует сохранение общего культурного кода.

Некоторые национально-патриотические силы утверждают, что независимые республики создали свою модель экономического развития, поэтому им нет необходимости вхождения в наднациональные союзы, в том числе и в Евразийский Экономический Союз (ЕЭС). Ведущие экономисты в Узбекистане очень сдержанно и осторожно относятся к вхождению республики в этот союз, аргументируя свои возражения тем, что узбекские предприниматели и производители не конкурентоспособны. При этом они утверждают, что 70 \% товарооборота Узбекистана приходится в страны России и Евразии [6]. Национальный парламент принял решение о том, что Узбекистан в работе ЕЭС будет участвовать как наблюдатель. Такая «мягкая самоизоляция» вряд ли приведет к расширению торгово-экономических отношений, она, по нашему мнению, является продолжением жёсткой внешней политики прежнего руководства, сторонники которого утверждали, что создание в Евразии наднациональных союзов усиливает роль России, и приведет к потере национального суверенитета. К чему привел такой подход, сегодня знает каждый узбекистанец.

В-третьих, культурный код опирается на фундаментально-имманентные особенности культуры, на ее общие философские законы. Культура связана с деятельностью человека, «она обращена не в прошлое, не к традиции, нависающей над настоящим. Ее основание, фундамент - творческая, созидательная активность человека, ведущая к личному совершенству» [5, с. 28]. Многие мыслители, ученые, представители искусства единодушны в том, что важнейшая составляющая жизни человека - создание культурных ценностей, т. е. очеловечивание социального бытия, гуманизация отношений, опирающихся на нравственные, позитивные и жизнеутверждающие начала, которые составляют ядро общего культурного кода. В настоящее время это особенно актуально:

«Под иссушающим ветром технопрогресса,

Идет антикультурная революция -

Вершится стихийный, неразумный

Пересмотр общечеловеческих ценностей»

$$
[7, \text { c. 11]. }
$$

Не следует забывать, что любая социальная реформа, с какими бы лозунгами она не осуществлялась, всегда повлияет (не всегда положительно и конструктивно), на психику людей, на их взаимоотношения, образ жизни. Социальные реформы должны детерминироваться культурным кодом народа. Но этот культурный код требует расширения этнокультурных связей, создания необходимых условий, пространства, где человек, не зависимо от его гражданства, национальности и этностереотипов, свободно мог бы проявить свои творческие способности, развивать свои интеллектуальные качества и зарабатывать деньги.

Следующим социальным фактором, способствующим формированию общего культурного кода, является близость духовных стремлений, социально-нравственных императивов народов Евразии. Религиозные верования и коммунитаризм (коммунитарные традиции) настолько сильны, что, несмотря на разнообразие, многоликость этнокультур, в них есть общие устойчивые ценности. К таким ценностям, прежде всего, относятся 
религиозные верования. Мы здесь имеем в виду не религии как таковые, а именно религиозность.

Евразиец глубоко верит в существование сверхестественных сил, это может быть бог, природа, шах, государь или вождь. Такая религиозность дает ему духовное удовлетворение, толерантное отношение к иноверцам и пришельцам, сплочению вокруг своего вождя, вере в существование справедливого жизнеустройства. Религиозность не исключает религию, но, здесь мы имеем в виду ее широкое толкование. Религиозность - основа жизнеустройства евразийца, выражает его мировоззрение, помогает ему выработать формы жизнедеятельности и отношения к внешнему миру. Поэтому, какие бы жизненные цели он ни ставил перед собой, они должны совпадать с его религиозностью. Все исследователи, которые изучали и изучают историю и культуру народов Евразии, единодушны в том, что религия и религиозность занимают доминирующее место в духовно-нравственной жизни евразийца, становлении евразийской идентичности. Христианство и ислам, как мировые религии, играют объединяющую роль разных народов и этнических групп, опираясь на них, государства осуществляют свои воспитательные и духовно-просветительные задачи. Кроме них в евразийском пространстве функционируют более 70 религиозных конфессий, организаций, которые помогают сохранять традиции, обряды и устное народное творчество. Игнорировать их социальное значение в формировании религиозности народов и сотрудничестве этнокультур просто невозможно.

Евразиец очень высоко ценит социальнонравственные императивы, моральные кодексы и дидактические опыты своих предков. Эти ценности помогают ему формировать нравственные идеалы, определить методы воспитания молодого поколения. Дидактические опыты предков не переоцениваются, а воспринимаются как вековая традиция, как нормы существования этноса. В связи с этим актуально высказывание Н. Бердяева о душе русского человека. «Русский человек, пишет он, - и в собственной душе чувствует необъятность, с которой трудно ему справиться. Широк русский человек, широк, как русская земля, как русские поля. Славянский хаос бушует в нем. Огромность русских пространств не способствовала выработке в русском человеке самодисциплины и самодеятельности, - он расплывается в пространстве» [8, с. 63-64]. Эта мысль философа не должно привести нас к мнению, что русский человек не ценит опыт и традиции предков, иначе не могло быть и речи о русской истории и русской культуре, как целостном и самобытном явлении. Проблемы, которые сегодня волнуют русского человека, волнуют и все народы Евразии, так как в их социально-нравственных императивах детерминирующую роль играет стремление к сотрудничеству. Самобытные социально-нравственные императивы и традиции народов Евразии не мешают этому сотрудничеству, а наоборот формируют полицентрический культурный ландшафт и укрепляют, развивают общий культурный код народов Евразии.

Сегодня, когда в жизни народов Евразии происходят коренные изменения, в культурный код их проникает гражданская культура, которая опирается не на этнотрадиции и этнокультуру, а на современные, склонные к модернизации и западным установкам, либерально демократические ценности. Под лозунгом глобализации и демократии активно пропагандируются формы гражданской культуры и ее ценности. Изменятся ли, если да, в какую сторону, парадигмы, принципы общего культурного кода народов Евразии? Сохранит ли общий культурный, «евразийский» код свою детерминирующую роль в сотрудничестве этнокультур, покажет время.

\section{Список литературы}

1. Олкотт М.Б. Второй шанс Центральной Азии. Москва, 2005. 487 с.

2. Рапай K. Культурный код. Как мы живем, что мы покупаем и почему. Москва, 2019. 234 с.

3. Фрейд 3. Психология бессознательного. Москва, 1989. 448 с.

4. Сорокин П.А. Человек. Цивилизация. Общество.-Москва: Изд. полит. литературы, 1992. $544 c$

5. Философия культуры: становление и развитие. Санкт Петербург, 1998. 446 с.

6. Шаханов M. Заблуждение цивилизации (Сага о нравах эпохи). Алма Аты, 1999. 276 с.

7. Бердяев Н. А. Судьба России. Опыты по психологии войны и национальности. Москва, 1918. $240 \mathrm{c}$.

8. Рафиков K. Интеграциялашув жараёни: тўғри йўлни танлаш. Ўзбекистоннинг Евроосиё иқтисодий иттифоқига кириши хусусида // Халк сўзи. 2020. 29 янв. 